\title{
Distribution and clinical significance of hepatitis B virus genotypes in Pakistan

Majid Mahmood ${ }^{1,2^{*}}$ (D, Muhammad Asim Anwar ${ }^{3}$, Azra Khanum ${ }^{4}$, Nasib Zaman ${ }^{5}$ and Abida Raza ${ }^{6}$

\begin{abstract}
Background: Hepatitis B virus (HBV) genotype and its role in disease progression and patients' response to antiviral treatment, is not well studied in Pakistan. This comprehensive study was aimed to determine the distribution of HBV genotypes in Pakistan and their possible association with phases of HBV infection.

Methods: A total of $840 \mathrm{HBsAg}$ positive samples was collected and tested for HBV DNA quantity. Samples below 100 $\mathrm{IU} / \mathrm{ml}$ were excluded from the study. A total of 715 samples representing all the six parts of the country were genotyped by type specific primer PCR method. Clinical data of only 384 patients was compared as the remaining 332 were either receiving antiviral treatment or their infection phase was not confirmed.

Results: Genotype D was found in 509 samples (71.2\%), genotype A in 55 samples (7.7\%) and mixed infection with genotypes A and D in 124 samples (17.3\%). Genotypes B, C and E were identified in less than $1 \%$ of the total samples. Genotype A, D and their mixture $(A+D)$ were compared for severity of HBV infection. Significant differences were not found in distribution of HBV genotypes among different disease stages.

Conclusion: HBV genotype $D$ was the predominant infection in all study areas of Pakistan followed by mixed genotypes infection (A+D) whereas genotype A has 10 times lower prevalence than genotype D. Genotypes B, C, E and $\mathrm{F}$ altogether make only $1.5 \%$ of the prevalence. Genotype do not appears to show the severity of liver disease.

Keywords: Hepatitis B virus, HBV genotypes, Liver disease progression, PCR

Abbreviations: AJK, Azad Jammu and Kashmir; ANOVA, Analysis of Variance; bp, Base Pairs; $\mathrm{ddH}_{2} \mathrm{O}$, Double Distilled Water; DNA, Deoxy ribo nucleic acid; FATA, Federally Administered Tribal Areas; FCT, Federal Capital Territory; HBsAg, Hepatitis B Surface Antigen; HBV, Hepatitis B Virus; HCC, Hepatocellular Carcinoma; HEC, Higher Education Commission; IU/ml, International Unit Per Milli Liter; KP, Khyber Pakhtoonkha; NORI, Nuclear Medicine, Oncology and Radiotherapy Institute; PCR, Polymerase Chain Reaction; PMAS, Pir Mehr Ali Shah; SPSS, Statistical Package for Social Sciences; USA, United States of America; ${ }^{\circ} \mathrm{C}$, Centigrade
\end{abstract}

\section{Background}

Hepatitis B virus (HBV) infection has been a major health problem as about 400 million people carry hepatitis B surface antigen worldwide [1], out of which, nearly 1 million die every year [2]. The infection rate of HBV has decreased significantly in developed countries like United States of America [3], where the acute HBV infection rate has fallen by $78 \%$ during 1990-2005 [4]. Unfortunately, in developing and underdeveloped countries including

\footnotetext{
*Correspondence: majid1133@gmail.com

'Department of Zoology, The University of Poonch, Rawalakot, Azad Jammu and Kashmir 12350, Pakistan

${ }^{2}$ Department of Zoology, Pir Mehr Ali Shah Arid Agriculture University,

Rawalpindi 46300, Pakistan

Full list of author information is available at the end of the article
}

Pakistan, the infection rate seems to have not decreased, even to any appreciable level. The failure in tackling the infection has been related to the high cost of antiviral drugs, lack of vaccination and public awareness about infection and the mismanagement to address the problem in Pakistan [5].

Eight HBV genotypes have been established on the basis of $8 \%$ or more nucleotide divergence in the genome. These genotypes are named as A, B, C, D [6], E, F [7, 8], G [9] and $H$ [10] which are common [11], while genotype I $[12,13]$ and $J[14]$ are also introduced as new genotypes but their status is questionable. HBV genotypes have specific pattern of distribution in different geographic regions and ethnic groups of the world. Genotype A is prevalent 
in Brazil, USA, Canada, Northwest Europe, South Asia, Central African countries, Tunisia and Benin [15-17]. Genotype B is common in Japan, Taiwan, Philippines, Hong Kong, China, Vietnam, Thailand, Indonesia and United States of America. Genotype C occurs in Australia, Polynesia, Melanesia, Micronesia, Indonesia, China, Hong Kong, Vietnam, Thailand, Japan, Korea, Taiwan, India, Solomon Islands, Brazil and USA. Genotype D is predominant in Mediterranean region, Spain, Albania, Czech Republic, Russia, Turkey, Middle East, Iran, Afghanistan, South Asia, Solomon Islands, Tunisia, Polynesia, Melanesia, Micronesia, Brazil and USA [17-19]. Genotype $E$ is endemic to Africa where it occurs only in some countries of the Western part of the continent while genotype $\mathrm{F}$ is widely distributed in new world. It has been reported from Alaska, Argentina, South America, Central America and Polynesia [17, 20]. Genotypes $G$ has been recorded from North America, France and Germany, genotype $\mathrm{H}$ from Central America, South America and Mexico while genotypes I and J were reported only from Vietnam and Japan respectively [17].

HBV genotypes have been reported to have significant association with progression of liver diseases, risk of cirrhosis, development of hepatocellular carcinoma (HCC), viral load, HBsAg sero-clearance, HBeAg sero-conversion and response to antiviral therapy [21]. Co-infection with two different virus genotypes has been reported to be associated with worse prognosis of the disease. Some studies showed that co-infection with HBV/B and HBV/C is associated with high viral load and more severe liver disease as compared to single genotype infection $[22,23]$. The patients with HBV/A have been reported to be more sensitive to interferon $\alpha$ treatment as compared to those infected with HBV/D [24] while the patients having infection with HBV/B have a higher response rate to interferon $\alpha$ treatment as compared to the patients infected with HBV/C [25]. Moreover, infection with genotype $\mathrm{C}$ alone was also found to be associated with significantly higher risks of liver cirrhosis and hepatocellular carcinoma as compared to genotype B infection [26, 27] while HBV/B shown an earlier HBsAg sero-clearance rate as compared to $\mathrm{HBV} / \mathrm{C}$ [28]. In another study, HBV/A was found to have significantly higher sero-conversion rate of $\mathrm{HBeAg}$ as compared to HBV/B, HBV/C, HBV/D and HBV/F [29]. From all the studies mentioned above it's quite clear that genotypes influence disease condition as well as response to treatment.

The picture regarding distribution of HBV genotypes in Pakistan and its association with disease stage has not been clearly understood yet. In fact, all of the available studies are mostly confined to specific cities/areas like Karachi (Sind) and Lahore (Punjab) and none of them contain data from other parts of the country. A vast range of areas from different regions of Pakistan still remains unexplored for HBV genotypes. Moreover, the existing state of knowledge regarding the distribution and prevalence of HBV genotypes in Pakistan seems to be sketchy and questionable too. For example, four studies $[5,30-32]$ are in agreement that genotype D infection is most prevalent in the country while three studies $[18,33,34]$ reported that genotype $\mathrm{C}$ is the most common ones in Pakistan. Yet in an another study, genotype $\mathrm{C}$ and D have been cited as most common HBV genotypes in Pakistan [35]. In view of the presence of the inadequate data, it was felt that a comprehensive study is required to determine the current distribution of HBV genotypes in all the six provinces of Pakistan and their possible association with different phases of HBV infection.

\section{Methods \\ Patients}

Eight hundred and forty (840) samples from HBsAg positive patients were collected during October 2010 to March 2013 from different locations of six regions of Pakistan which include Punjab and Federal Capital Territory of Islamabad $(n=359)$; Khyber Pakhtoonkhwa along with Federally Administered Tribal Areas $(n=115)$; Azad Jammu and Kashmir $(n=81)$; Gilgit-Baltistan $(n=111)$; Sind province including Karachi city $(n=107)$; and Baluchistan $(n=67)$. The sampling sites and the details of patients are given in Fig. 1 and Table 1 respectively. All the patients were diagnosed as chronic HBV carriers. Serum samples were acquired from the different hospitals and diagnostic laboratories of the above regions where they were originally collected for routine diagnostic purposes. All the available data of clinical and demographic importance were collected at the time of sample collection by filling out a questionnaire. All the samples were then brought to Nuclear Medicine, Oncology and Radiotherapy Institute (NORI), Islamabad and stored at $-25{ }^{\circ} \mathrm{C}$ for further analysis. The samples were tested for positivity and quantity of HBV DNA. Only the samples having more than $100 \mathrm{IU} / \mathrm{ml}$ of viral load were subjected to HBV genotyping (Table 1). The samples with lower than $100 \mathrm{IU} / \mathrm{ml}$ of viral load were excluded because their genotyping was not successful in most of the cases. All the routine tests including HBsAg, ALT, and anti-HBe were performed in Central Laboratories, NORI using commercially available kits (Abott Diagnostics, USA).

The stage of HBV infection was primarily assigned by the local physician and further confirmed by the status of different HBV markers and biochemical tests. Only 384 patients were included in the study of genotypes influence on disease stage. All the patients (331) who had already received antiviral treatment or had co-infection with HIV, HCV or HDV were excluded from this part of study. The liver disease stage was primary assigned by 


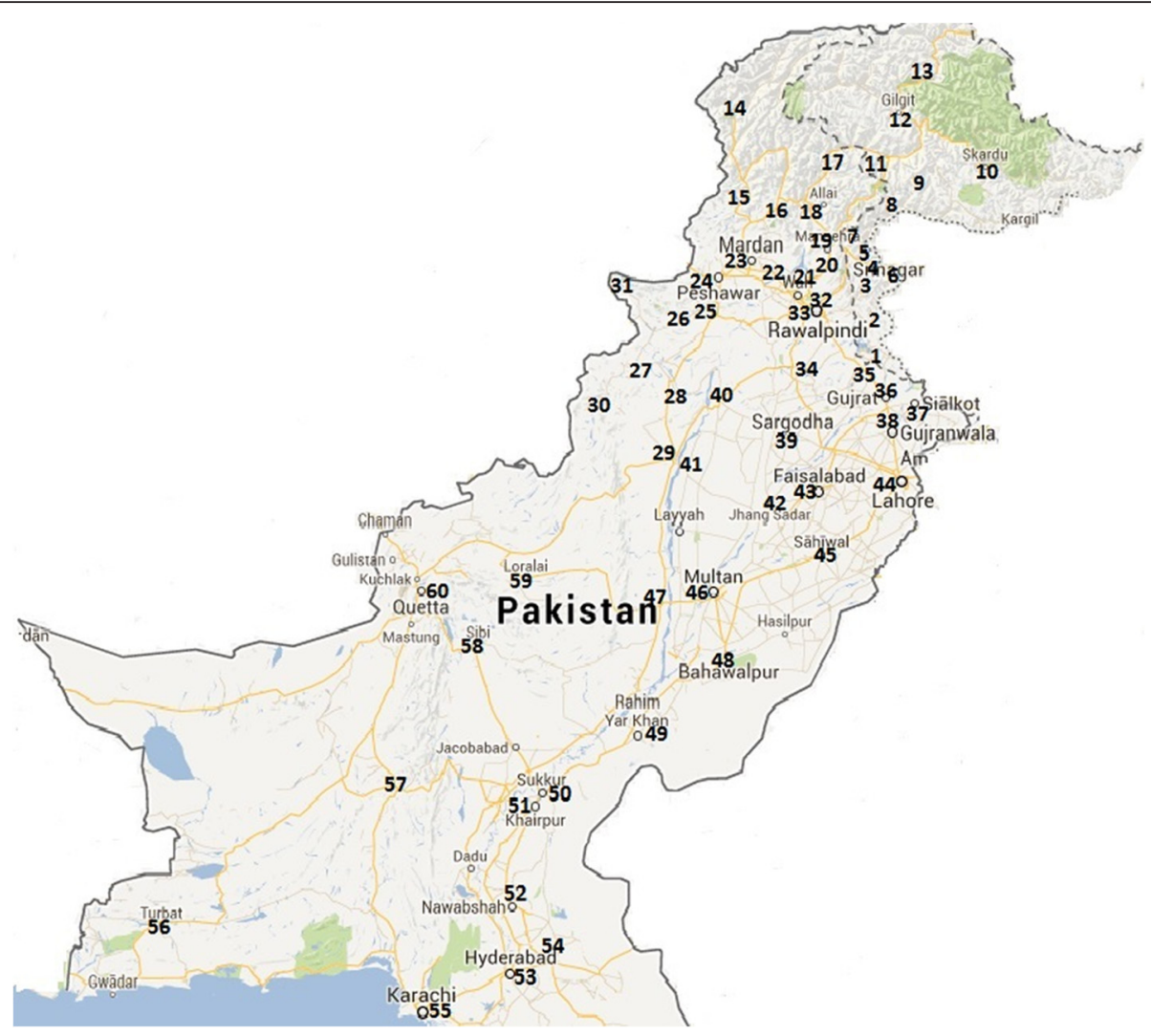

Fig. 1 The map shows the sampling sites in all regions of Pakistan. Sites are indicated with numerals. Sites: 1. Mirpur; 2. Kotli; 3. Palandari; 4. Rawalakot; 5. Bagh; 6. Kahuta; 7. Muzaffarabad; 8. Neelum; 9. Astor; 10. Sikardu; 11. Diamir; 12. Gilgit; 13. Hunza; 14. Chitral; 15. Dir; 16. Swat; 17. Kohistan; 18. Batgram; 19. Mansehra; 20. Abottabad; 21. Haripur; 22. Nowshera; 23. Mardan; 24. Peshawar; 25. Kohat; 26. Hangu; 27. Bannu; 28. LakkiMarwat; 29. D I Khan; 30. Wana; 31. Parachinar; 32. Islamabad; 33. Rawalpindi; 34; Chakwal; 35. Jhelum; 36. Gujrat; 37. Sialkot; 38. Gujranwala; 39. Sargodha; 40. Mianwali; 41. Bhakkar; 42. Jhang; 43. Faisalabad; 44. Lahore; 45. Sahiwal; 46. Multan; 47. D.G. Khan; 48. Bahawalpur; 49. Rahim Yar Khan; 50. Sukhar; 51. Khairpur; 52. Nawabshah; 53. Hyderabad; 54. Mirpur Khas; 55. Karachi; 56. Turbat; 57; Khuzdar; 58. Sibi; 59. Loralai; 60. Quetta. Regions: 1-8, Azad Jammu \& Kashmir; 9-13, Gilgit-Baltistan; 14-31, Khyber Pakhtunkhwa; 32, Federal Capital Territory of Islamabad (FCT); 33-49, Punjab; 50-55, Sind; 56-60, Baluchitan

classified gastroenterologists and then the disease phase was further confirmed on the base of patients' HBV viral load, ALT levels, HBeAg status and the presence or absence of anti HBe antibodies (Table 3). The study was approved by institutional ethics committee of PMAS Arid Agriculture University Rawalpindi and each patient gave written consent.

\section{HBV DNA extraction and quantification}

HBV DNA was extracted from the plasma according to manufacturer's protocol using "Instant Virus DNA kit" (AJ
Roboscreen, Analytikajena Biosolutions, GmbH, Germany) while the DNA was quantified using RoboGene ${ }^{\circ}$ HBV Quantification kit (AJ Roboscreen, analytikajena Biosolutions, $\mathrm{GmbH}$, Germany) according to manufacturer's instructions.

\section{HBV genotyping}

The genotyping was performed using PCR method with genotype specific primers described by Naito et al. [36] with some modifications in cycling profile and PCR constituents. For regular PCR, $10 \mu \mathrm{l}$ of $\mathrm{GoTaq}^{\circ}$ Green Master mix (Promega, USA), $1 \mu \mathrm{l}$ each of universal primers P1A

Table 1 Samples collected and selected for HBV genotyping from different regions of the country

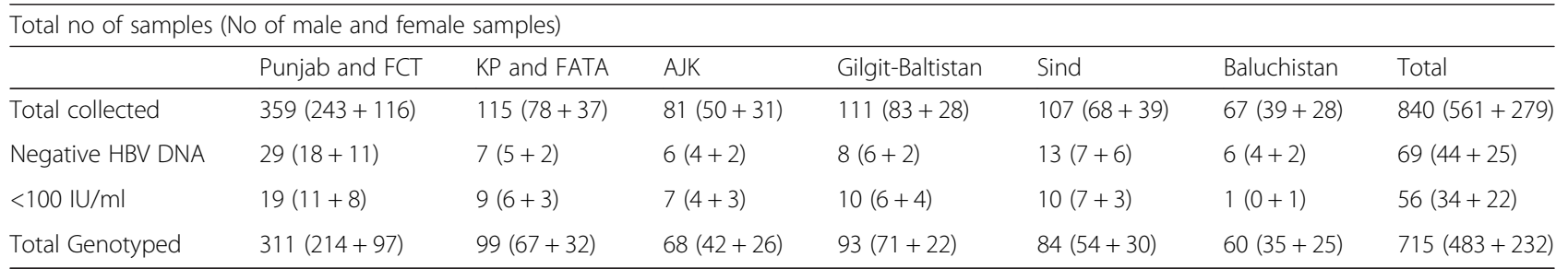


and S1-2, $2 \mu \mathrm{l}$ of $\mathrm{ddH}_{2} \mathrm{O}$ and $6 \mu \mathrm{l}$ of diluted template (DNA) were used to make $20 \mu \mathrm{l}$ of reaction volume. The thermal profile was; $10 \mathrm{~min}$ at $95{ }^{\circ} \mathrm{C}$, then 30 cycles of; $94{ }^{\circ} \mathrm{C}$ for $20 \mathrm{~s}, 55^{\circ} \mathrm{C}$ for $20 \mathrm{~s}$ and $72{ }^{\circ} \mathrm{C}$ for $1 \mathrm{~min}$, then another $7 \mathrm{~min}$ at $72{ }^{\circ} \mathrm{C}$ (ABI 9700, USA). Two mixes were used in nested PCR. Mix 1 had the forward primers for genotype $\mathrm{A}, \mathrm{B}$ and $\mathrm{C}$ with a common reverse primer while mix two had reverse primers for genotypes D, E and F with common forward primer. Two $\mu$ l of product from 1st round of PCR were added to each mix as DNA template with $8 \mu \mathrm{l}$ of $\mathrm{GoTaq}^{\circ}$ Green Master mix, $8 \mu \mathrm{l}$ of $\mathrm{ddH} 2 \mathrm{O}$ and $1 \mu \mathrm{l}$ of each primer to make $22 \mu \mathrm{l}$ of final volume. The cycling profile for nested PCR was; $95^{\circ} \mathrm{C}$ for $10 \mathrm{~min}$, then 40 cycles of $94{ }^{\circ} \mathrm{C}$ for $45 \mathrm{~s}, 63{ }^{\circ} \mathrm{C}$ for $20 \mathrm{~s}$, and $72{ }^{\circ} \mathrm{C}$ for $60 \mathrm{~s}$, and then another $7 \mathrm{~min}$ at $72{ }^{\circ} \mathrm{C}$ (ABI 9700, USA). Products were run on $2 \%$ agarose gel which was stained in a solution of ethidium bromide, and then observed under ultraviolet fluorescence (BioRad Gel Doc$\mathrm{XR}$, USA). Amplified products in mix 1 were $68 \mathrm{bp}$, $281 \mathrm{bp}$ and $122 \mathrm{bp}$ in size for genotypes A, B and C respectively while the product sizes in mix 2 were $119 \mathrm{bp}$, $167 \mathrm{bp}$ and $97 \mathrm{bp}$ for genotypes D, E and F respectively. The product's size was estimated with reference to a 50bp DNA ladder (GeneRuler ${ }^{\text {Tw }}$ Fermentas) and the genotype was determined for each sample according to the sizes of DNA product obtained in both mixes (Fig. 2). The term untypable was assigned to those samples which had higher than $100 \mathrm{IU} / \mathrm{ml}$ of viral load but were not successfully genotype or their genotype was not identified by the method.

\section{Statistical analysis}

Chi square test was applied to evaluate the relationship HBV genotype and HBV infection phase with each other as well as with patients' gender while one way analysis of variance (ANOVA) was performed to analyze the relationship of HBV genotype and HBV infection phase with

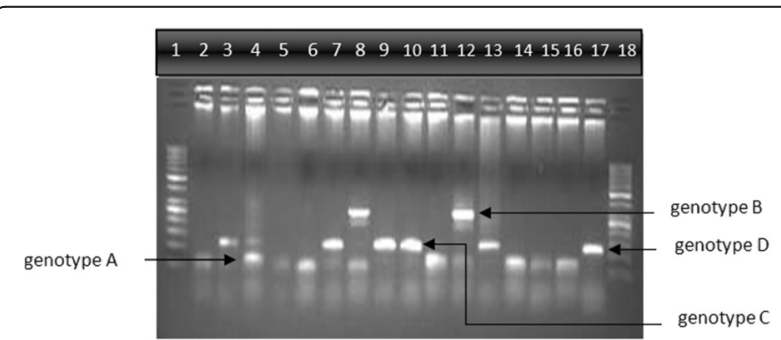

Fig. 2 Amplified PCR products on $2 \%$ gel showing bands for four genotypes. Lanes $2,4,6,8,10,12,14$ and 16: the product bands of mix 1. Lanes $3,5,7,9,11,13,15$ and 17: the product bands of mix 2 . Lanes 1 and 18: 50 bp DNA ladder. lanes 2+3: genotype D. lanes 4 + 5: genotype A. lanes 6+ 7: genotype A + D. lanes 8+9: genotype $A+B+D$. lanes $10+11$ : genotype $C$ and a nonspecific band. lanes $12+13$ : genotype $B+D$. lanes $14+15$ : genotype A. lanes $16+17$; Genotype A + D the age of patients. A value of $p$ less than 0.05 was considered as statistically significant. SPSS version- 16.0 was used for all the analyses.

\section{Results}

Out of total 840 samples, 125 were excluded from the study as HBV DNA was not detected in them. The remaining 715 samples were further analyzed (Table 1).

\section{Regional distribution of HBV genotypes}

Out of the 715 samples taken for genotyping, 699 were successfully genotyped while $16(2.2 \%)$ remained untypable. HBV genotypes A, B, C, D and E were detected in 55 (7.7 \%), 4 (0.6 \%), 6 (0.8 \%), 509 (71.2 \%) and 1 (0.1\%) samples respectively (Table 2). A total of 124 (17.3\%) patients were infected with more than one genotype i.e. mix genotype infection. The mix genotype infection comprised six combinations in different proportions which were $-\mathrm{A}+\mathrm{B}$ (0.3\%), A + D (13.7 \%), B + D (1.9\%), C + D (1.0\%), E + D $(0.1 \%)$ and $\mathrm{A}+\mathrm{B}+\mathrm{D}(0.3 \%)$.

Concerning the regions included in this study, genotype $\mathrm{D}$ was always the predominant one with the prevalence ranging from 63.3 to $88.3 \%$ (Table 2). Genotype A and the mix genotype combination $\mathrm{A}+\mathrm{D}$ was also present in all regions. The prevalence of genotype A, D and mix genotypes respectively was $10 \%, 63.3 \%$ and $23.5 \%$ in Punjab and FCT region; $7 \%, 68 \%$ and $18 \%$ in $\mathrm{KP}$ and FATA region; $4.4 \%, 82.3 \%$ and $11.8 \%$ in AJK region; $3.2 \%, 80.6 \%$ and $12.8 \%$ in Gilgilt-Baltistan region; $10.7 \%, 72.6 \%$ and $13 \%$ in Sind region; $3.3 \%$, $88.3 \%$ and $5 \%$ in Baluchistan region (Fig. 3).

Multiple genotype infections presented the second more prevalent group of genotypes with $17.3 \%$ of the total samples infected with 6 different combinations of genotypes (Table 2). Mix infection with $\mathrm{A}+\mathrm{D}$ genotype was the major combination found among multiple genotype infections which was $98 / 124$ of the samples. Other mix genotype combinations identified were $\mathrm{B}+\mathrm{D}, \mathrm{C}+\mathrm{D}, \mathrm{A}+\mathrm{B}, \mathrm{A}+$ $\mathrm{B}+\mathrm{D}$ and $\mathrm{E}+\mathrm{D}$ which were $1.9 \%, 1.0 \%, 0.3 \%, 0.3 \%$ and $0.1 \%$ of the samples respectively. None of the combinations except $\mathrm{A}+\mathrm{D}$ was found in more than $2 \%$ of the samples. This combination was detected from all parts of the Pakistan, though it was highest in Punjab and FCT region $(21.8 \%)$ as compared to all other parts (Table 2).

Distribution HBV genotypes in different phases of disease All statistical comparisons performed for genotypes A, D and $\mathrm{A}+\mathrm{D}$ as the other genotypes and their combinations in mix infections were rare (Table 2). Out of total 715 patients included in the study, 331 (46.3\%) had either already received antiviral treatment or had co-infection with HIV, HCV or HDV or had genotype other than A and D. Thus the remaining 384 (53.7\%) patients who were not exposed to any treatment till the time of sample 
Table 2 Distribution of HBV genotypes and their combinations in the samples taken from different regions of Pakistan. The numbers and proportions (\%) are given against each genotype or the genotypic combination

\begin{tabular}{|c|c|c|c|c|c|c|c|}
\hline Genotype & KP and FATA & AJK & Gilgit-Baltistan & Sind & Punjab and FCT & Baluchistan & Total \\
\hline $\bar{A}$ & $7(7)$ & $3(4.4)$ & $3(3.2)$ & $9(10.7)$ & $31(10)$ & $2(3.3)$ & $55(7.7)$ \\
\hline B & $2(2)$ & 0 & $1(1.1)$ & 0 & $1(0.3)$ & 0 & $4(0.6)$ \\
\hline C & $3(3)$ & $1(1.5)$ & 0 & 0 & $1(0.3)$ & $1(1.7)$ & $6(0.8)$ \\
\hline D & $67(68)$ & $56(82.3)$ & 75 (80.6) & $61(72.6)$ & 197 (63.3) & $53(88.3)$ & $509(71.2)$ \\
\hline$E$ & 0 & 0 & 0 & $1(1.2)$ & 0 & 0 & $1(0.1)$ \\
\hline Mix & $18(18)$ & $8(11.8)$ & $11(12.8)$ & $11(13)$ & $73(23.5)$ & $3(5)$ & $124(17.3)$ \\
\hline$A+B$ & $2(2.0)$ & 0 & 0 & 0 & 0 & 0 & $2(0.3)$ \\
\hline$A+D$ & $9(9.1)$ & $5(7.3)$ & $4(4.3)$ & $9(10.7)$ & 68 (21.8) & $3(5.0)$ & $98(13.7)$ \\
\hline$B+D$ & $2(2.0)$ & 0 & $6(6.4)$ & $2(2.3)$ & $4(1.3)$ & 0 & $14(1.9)$ \\
\hline$C+D$ & $4(2.0)$ & $3(4.4)$ & 0 & 0 & 0 & 0 & $7(1.0)$ \\
\hline$E+D$ & 0 & 0 & 0 & 0 & $1(0.3)$ & 0 & $1(0.1)$ \\
\hline$A+B+D$ & $1(1.0)$ & 0 & $1(1.1)$ & 0 & 0 & 0 & $2(0.3)$ \\
\hline Untypable & $2(2.0)$ & 0 & $3(3.2)$ & $2(2.3)$ & $8(2.5)$ & $1(1.7)$ & $16(2.2)$ \\
\hline Total & 99 & 68 & 93 & 84 & 311 & 60 & 715 \\
\hline
\end{tabular}

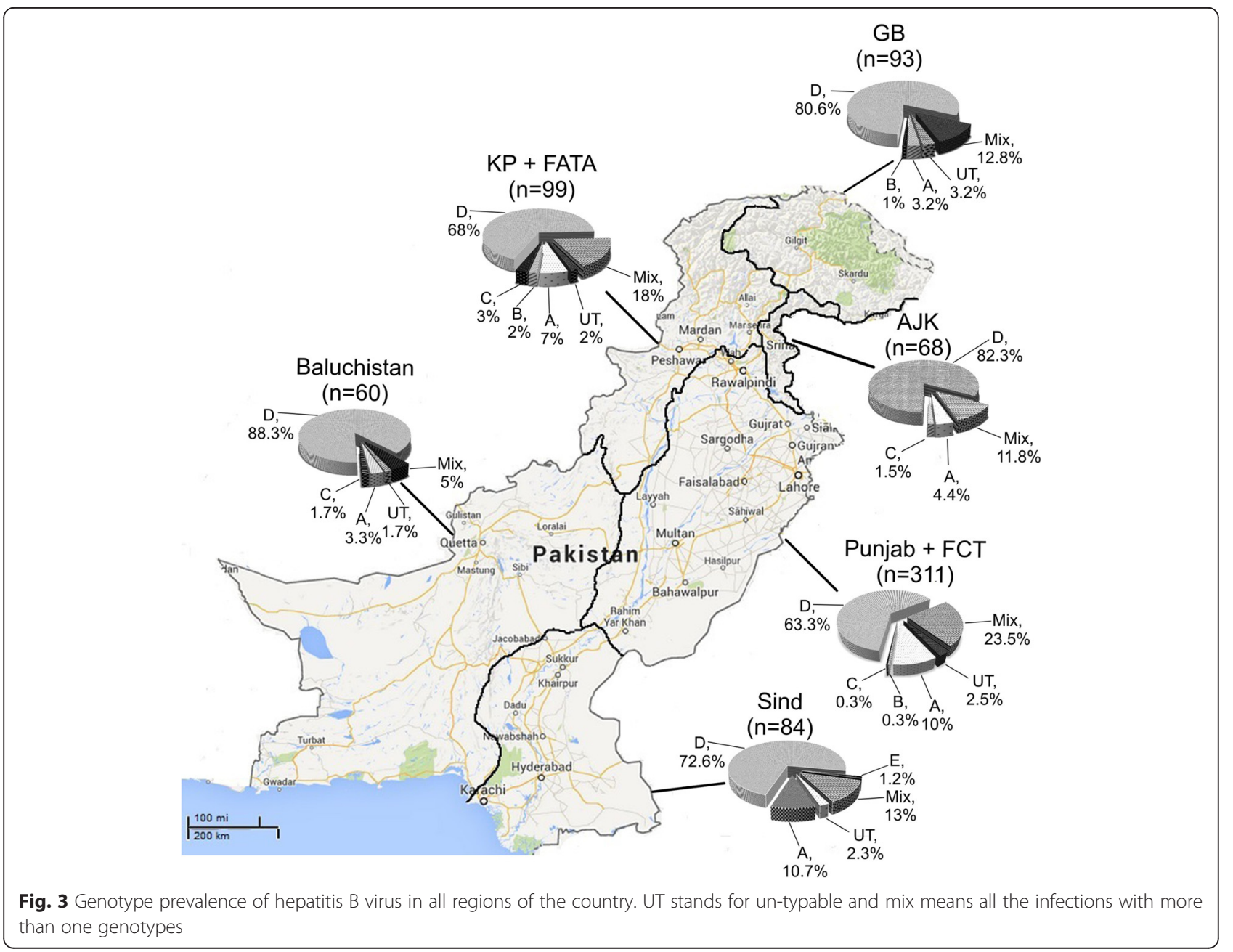


collection were classified in four different phases of liver disease: $56(14.6 \%)$ were in immune control phase, 89 (23.2 \%) in immune tolerant phase, 153 (39.8 \%) in immune clearance phase and $86(22.4 \%)$ in immune escape phase (Table 3). None of the patients had liver cirrhosis or hepatocellular carcinoma in this study. The mean age of the patients and gender ratio was statistically equal among all the disease phases. Genotype D $(n=279)$ was the most prevalent in all groups of patients with 36 patients in immune control group, 67 in immune tolerant group, 112 in immune clearance and 64 in immune escape group. The second more prevalent was the mix infection $\mathrm{A}+\mathrm{D}$ $(n=62)$ with $13,12,26$ and 11 cases in immune control, immune tolerant, immune clearance and immune escape groups respectively. Genotype A $(n=43)$ was the least prevalent with 7, 10, 15 and 11 cases in immune control, immune tolerant, immune clearance and immune escape phases respectively. The differences in distribution of genotypes in disease phases were not statistically significant. Similarly, there were no statistical differences of age and gender among the three genotype groups compared (Table 3).

\section{Discussion}

The present study is the first of its kind which included a cohort of 715 patients with chronic HBV infection from all six regions of Pakistan. The study analyzed the patients for HBV genotypes and their possible associations with liver disease severity in 384 consecutive chronic HBV carriers. According to the results, genotypes A, B, C, D, E and mix genotype infections with 6 different genotypic combinations are present in Pakistan, but the majority of patients $(92.6 \%)$ were infected with either genotype $D$, or genotype $A$ or a mixture of both $(\mathrm{A}+\mathrm{D})$. The pre-dominant genotype in all regions was $\mathrm{D}$ followed by genotype $\mathrm{A}$ and mix genotype infection with A+D. Genotypes B, C, E and F were rare and collectively form only $1.5 \%$ of the total prevalence.

HBV genotypes were not studied exclusively from all over the Pakistan so far. Table 4 summarizes some available data on the topic from Pakistan along with the results of present study. Most of the available data are from Karachi and Lahore or Punjab and Sind while none of the study has explored the regions of FATA, GilgitBaltistan, AJK, some parts of Khyber Pakhtoonkha province and most of the Baluchistan province. Though three studies carried out by Awan et al. [18], Alam et al. [30] and Idrees et al. [34] investigated the provinces of $\mathrm{KP}$ and Baluchistan additionally but the number of samples taken were not satisfactory to conclude the genotype distribution in these provinces (Table 4). None of the studies included the regions of Gilgit-Baltistan, AJK and FATA. Two of these three $[18,34]$ studies reported genotype $C$ as predominant while one [30] found genotype D as predominant one. Genotype B which was not reported from Pakistan in any other study has also been reported in all three of these studies from 18 to $25 \%$ of the samples. These results are contradictory to these studies.

All the studies confined to the samples from Punjab and Sind reported genotype D as predominant except one [33] which reported prevalence of genotype $\mathrm{C}$ and $\mathrm{D}$ as 75 and $25 \%$ respectively. The remaining six studies $[5,31,32,37-39]$ reported genotype $\mathrm{D}$ as the commonest one in Pakistan with percentage distribution of 59, $84,70,98.2,84$ and $93.2 \%$ respectively (Table 4 ). The results of present study representing all parts of the country with significant number of samples is in agreement with the later group $[5,31,32,37-39]$ that reported genotype $\mathrm{D}$ as the most prevalent $\mathrm{HBV}$ genotype in Pakistan. Genotype A was found to be the second more prevalent single genotype infection with $7.7 \%$. Genotype A was also reported in most of the previous studies $[5,18,30,32,34,39]$ in different proportions ranging from 0.8 to $21.4 \%$ and a mean prevalence of $11.7 \%$ (Table 4 ). Genotype B was present only in $0.6 \%$ of present study samples while it was reported in proportions ranging from 18 to $24.5 \%$ by previous studies from Pakistan $[18,30,34]$. None of the other studies reported genotype $B$ infection, however mix infections involving genotype $B$ were reported by some studies $[18,30,31,38]$ as high as $16 \%$ of the samples (Table 4). Genotype C was detected

Table 3 Characteristics of patients infected with different HBV genotypes $(n=384)$

\begin{tabular}{|c|c|c|c|c|c|}
\hline Characteristics & & Genotype A & Genotype D & Genotype A + D & Sig. \\
\hline Number of patients (\%) & & $43(11.2)$ & $279(72.7)$ & $62(16.1)$ & \\
\hline Age $($ Mean $\pm S D)$ & & $32.4 \pm 11.7$ & $34.1 \pm 12.1$ & $35.1 \pm 12.8$ & $N S^{a}$ \\
\hline Gender (M/F) & & $32 / 11$ & $202 / 77$ & $40 / 22$ & $N S^{b}$ \\
\hline Immune Control $(N=56)$ & normal ALT, HBeAg negative, anti HBe positive, low viral load & $7(16.3 \%)$ & $36(12.9 \%)$ & $13(21.0 \%)$ & $N S^{b}$ \\
\hline Immune Tolerant $(N=89)$ & normal ALT, HBeAg positive, anti HBe negative, high viral load & $10(23.2 \%)$ & $67(24.0 \%)$ & $12(19.3 \%)$ & $N S^{b}$ \\
\hline Immune Clearance $(N=153)$ & elevated ALT, HBeAg positive, high viral load & $15(34.9 \%)$ & $112(40.1 \%)$ & $26(41.9 \%)$ & $N S^{b}$ \\
\hline Immune Escape $(N=86)$ & $\begin{array}{l}\text { Normal or elevated ALT, HBeAg negative, anti HBe positive, } \\
\text { High HBV DNA, }\end{array}$ & $11(25.6 \%)$ & $64(22.9 \%)$ & $11(17.7 \%)$ & $\mathrm{NS}^{\mathrm{b}}$ \\
\hline
\end{tabular}

ane way Analysis of Variance, ${ }^{\mathrm{b} P e a r s o n}$ Chi Square Test, NS for non significant 
Table 4 The prevalence of different HBV genotypes in our study compared to previously published studies

\begin{tabular}{|c|c|c|c|c|c|c|c|c|c|c|c|}
\hline \multirow[t]{2}{*}{ Source } & \multirow[t]{2}{*}{ Place of sampling } & \multirow[t]{2}{*}{ Sample size } & \multicolumn{9}{|c|}{ Proportion of genotype as percent of total samples } \\
\hline & & & A & B & C & D & $\mathrm{E}$ & $\mathrm{F}$ & Mix & Mixed combinations & UT \\
\hline Hanif et al., 2013 [5] & Karachi, Islamabad/Rawalpindi & $200(40,160)$ & 10 & - & - & 59 & - & - & 31 & $A+D$ & - \\
\hline Awan et al., 2010 [18] & Punjab, KP, Sind, Baluchistan & $300(222,36,26,15)$ & 14 & 18 & 28 & 13 & 0.6 & 1.3 & 16 & $\begin{array}{l}A+B+D, A+D+F, A+C, A+D, A+E, A+F \\
B+C, B+E, C+D\end{array}$ & 10.3 \\
\hline Ahmed et al., 2009 [39] & Punjab, Sind & 236 & 0.8 & - & 5.9 & 93.2 & - & - & - & - & - \\
\hline Baig et al., 2009 [32] & Karachi & 315 & 20 & - & - & 70 & - & - & 10 & $A+D$ & - \\
\hline Noorali et al., 2008 [31] & Karachi & 180 & - & - & - & 84 & - & - & 16 & $B+D$ & - \\
\hline Hakim et al., 2008 [38] & Karachi & 180 & - & - & - & 84 & - & - & 16 & $B+D$ & - \\
\hline Alam et al., 2007 [30] & Punjab, KP, Sind Baluchistan & $110(30,28,25,18)$ & 4.5 & 24.5 & - & 60 & - & - & 2.7 & $A+D, B+D$ & 8.2 \\
\hline Abbas et al., 2006 [37] & Karachi & 109 & - & - & - & 98.2 & - & - & 1.8 & $A+D$ & - \\
\hline Idrees et al., 2004 [34] & Punjab, KP, Sind Baluchistan & 112 (Details not available) & 21.4 & 17.9 & 41.1 & 8.0 & - & - & 7.1 & Details not available & 4.5 \\
\hline Naaz, 2001 [33] & Lahore & 12 & - & - & 75 & 25 & - & - & - & - & - \\
\hline This study & Punjab, KP, Sind, Baluchistan, AJK, Gilgit-Baltistan & $715(311,99,84,60,68,93)$ & 7.7 & 0.6 & 0.8 & 71.2 & 0.1 & - & 17.3 & $A+D, B+D, C+D, A+B, A+B+D, E+D$ & 2.2 \\
\hline
\end{tabular}

UT stands for Un-typable 
in only $0.8 \%$ of the samples in our study while three previous studies [18, 33, 34] have reported it as predominant genotype in Pakistan, whereas one study [39] reported it as second more prevalent genotype in the country. Genotype $\mathrm{C}$ was not reported by any of the other six studies (Table 4). Genotype E and F were not reported by any previous study except [18] which reported them in the proportions of 0.6 and $1.3 \%$. As already mentioned, genotypes $\mathrm{E}$ and $\mathrm{F}$ are endemic to Africa and the New World respectively $[17,20]$ and the fact that they were found in only 1 case (genotype E) was quite expected. Present study thus supports the conclusion that not only genotypes $\mathrm{E}$ and $\mathrm{F}$ but also genotypes $\mathrm{B}$ and $\mathrm{C}$ were rare in Pakistan (Table 4).

The relationship of HBV genotypes with liver disease is still not very clear. Although some studies have reported that HBV genotype influence the severity of liver disease and course of chronic HBV infection [26, 28, 40-44]. Some other studies showed that HBV genotype had no influence on course of HBV infection [43, 45, 46]. Present study is in concordance with the later group $[43,45,46]$. Most of the studies compared genotype B and C in Asia and reported that the latter is more associated to severe liver disease than the former. On the other hand the genotype $B$ is associated with an early HBeAg sero-conversion, more sustained remission after $\mathrm{HBeAg}$ sero-conversion, less active hepatic necroinflammation, a slower rate of progression to cirrhosis, and a lower rate of hepatocellular carcinoma (HCC) development as compared to genotype C $[26,28,41,43,44]$. A study from Pakistan compared genotype $\mathrm{A}, \mathrm{D}$ and $\mathrm{A}+\mathrm{D}$ for their association with complex liver diseases and concluded that genotype A is associated with more complex liver disease [47]. However, present study did not find any association of genotypes with disease stage. The relatively high prevalence of mix infection with genotypes $\mathrm{A}+\mathrm{D}$ is a confirmation of the data reported by several previous findings about HBV genotyping in Pakistan [5, 18, 30, 32, 34, 37].

\section{Conclusions}

In conclusion, it has been observed in the present study that the distribution of HBV genotypes was almost similar in all the regions of Pakistan. Genotype D was the most common one $(71.2 \%)$ followed by mix infection with genotypes $\mathrm{A}$ and $\mathrm{D}(17.3 \%)$ and genotype $\mathrm{A}$ (7.7 \%). Although genotypes B, C, E and F were also detected but their prevalence was very low $(1.5 \%)$. Furthermore, genotype was not found to have any significant influence on liver disease progression in Pakistan.

\section{Acknowledgements}

The authors are thankful to Professor Ferruccio Bonino and Professor Mirza Azhar Beg for critically reviewing the article and setting its language.

\section{Funding}

The study was partially funded by Higher Education Commission of Pakistan (HEC) in the form of indigenous PhD fellowship (PIN: 074-2673-Bm4-145). There was no role of the funding body in design of the study, data collection, analysis and publication.

\section{Availability of data and materials}

Data sharing not applicable to this article as no datasets were generated or analyzed during the current study. Original data may be obtained by email to corresponding author.

\section{Authors' contributions}

MM, AR and AK conceived and designed the study and experiments. MM, MAA and NZ performed the experiments and collected the data. MM and NZ analyzed the data. MM prepared the initial draft of manuscript. AK, AR, and MAA critically reviewed and revised the manuscript. All authors read and approved the final manuscript.

\section{Competing interests}

The authors declare that they have no competing interests. The study is a part of PhD thesis of Majid Mahmood.

\section{Consent for publication}

Not applicable.

\section{Ethics approval and consent to participate}

The study was approved by institutional ethics committee of PMAS Arid Agriculture University Rawalpindi and each patient gave written consent before the start of study.

\section{Author details}

${ }^{1}$ Department of Zoology, The University of Poonch, Rawalakot, Azad Jammu and Kashmir 12350, Pakistan. ${ }^{2}$ Department of Zoology, Pir Mehr Ali Shah Arid Agriculture University, Rawalpindi 46300, Pakistan. ${ }^{3}$ Department of General Medicine, Pakistan Atomic Energy Commission (PAEC) General Hospital, Islamabad 44000, Pakistan. ${ }^{4}$ Barani Institute of Management Sciences (BIMS), Rawalpindi 46300, Pakistan. ${ }^{5}$ Center for Biotechnology \& Microbiology, University of Swat, Swat 19130, Pakistan. ${ }^{6}$ Diagnostic Department, Nuclear Medicine, Oncology and Radiotherapy Institute (NORI), Islamabad 44000, Pakistan.

Received: 19 April 2016 Accepted: 3 August 2016

Published online: 26 August 2016

\section{References}

1. Bonino F. Introduction to hepatitis B virus heterogeneity - a means to personalized care. Antivir Ther. 2010;15 Suppl 3:1-2.

2. Boesecke C, Wasmuth JC. Hepatitis B. In: Mauss S, Berg T, Rockstroh J, Sarrazin C, Wedemeyer H, editors. Hepatology a clinical text book. 3rd ed. Wuppertal: Flying Publishers; 2012. p. 32-35.

3. Rantala M, Van de Laar MJ. Surveillance and epidemiology of hepatitis B and C in Europe - a review. Eurosurveillance. 2008;13(21):1-8.

4. Wasley A, Grytdal S, Gallagher K. Surveillance for acute viral hepatitis-United States. MMWR Surveill Summ. 2008;57:1-24.

5. Hanif M, Zaidi P, Habib S, Ahmed A, Raza A, et al. Study of genotypes and subgenotypes of Hepatitis B virus prevalent in big cities of Pakistan. Afr J Microbiol Res. 2013:3:152-7.

6. Okamoto H, Tsuda F, Sakugawa H, Sastrosoewignjo RI, Imai M, et al. Typing hepatitis $\mathrm{B}$ virus by homology in nucleotide sequence: comparison of surface antigen subtypes. J Gen Virol. 1988;69:2575-83.

7. Naumann H, Schaefer S, Yoshida CFT, Gaspar AMC, Repp R, et al. Identification of a new hepatitis-B-virus (HBV) genotype from Brazil that expresses HBV surface antigen subtype adw4. J Gen Virol. 1993;74:1627-32.

8. Norder H, Courouce AM, Magnius LO. Complete genomes, phylogenetic relatedness, and structural proteins of six strains of the hepatitis B virus, four of which represent two new genotypes. Virol. 1994;198:489-503.

9. Stuyver L, De Gendt S, Van Geyt C, Zoulim F, Fried M, et al. A new genotype of hepatitis B virus: complete genome and phylogenetic relatedness. J Gen Virol. 2000;81:67-74 
10. Arauz-Ruiz P, Norder H, Robertson BH, Magnius LO. Genotype H: a new Amerindian genotype of hepatitis B virus revealed in Central America. J Gen Virol. 2002;83:2059-73.

11. Kay A, Zoulim F. Hepatitis B virus genetic variability and evolution. Virus Res. 2007;127:164-76.

12. Tran TT, Trinh TN, Abe K. New complex recombinant genotype of hepatitis $B$ virus identified in Vietnam. J Virol. 2008;82:5657-63.

13. Olinger CM, Jutavijittum P, Hubschen JM, Yousukh A, Samountry B, et al. Possible new hepatitis B virus genotype, southeast Asia. Emerg Infect Dis. 2008;14:1777-80.

14. Tatematsu K, Tanaka Y, Kurbanov F, Sugauchi F, Mano S, et al. A genetic variant of hepatitis $B$ virus divergent from known human and ape genotypes isolated from a Japanese patient and provisionally assigned to new genotype J. J Virol. 1995;83:10538-47.

15. Kidd-Ljunggren $\mathrm{K}$, Oberg $M$, Kidd $A H$. The hepatitis B virus $X$ gene: analysis of functional domain variation and gene phylogeny using multiple sequences. J Gen Virol. 1995;76:2119-30.

16. Bowyer SM, Staden LV, Kew MC, Sim JG. A unique segment of the hepatitis $B$ virus group A genotype identified in isolates from South Africa. J Gen Virol. 1997;78:1719-29.

17. Bonino F, Teerha P, Brunetto MR, Yun-Fan L. Diagnostic markers of chronic hepatitis B infection and disease. Antivir Ther. 2010;15 Suppl 3:35-44.

18. Awan Z, Idrees M, Amin I, Butt S, Afzal S, et al. Pattern and molecular epidemiology of Hepatitis B virus genotypes circulating in Pakistan. Infect Genet Evol. 2010;8:1242-6.

19. Datta S. An overview of molecular epidemiology of hepatitis B virus (HBV) in India. Virol J. 2008:5:156.

20. Nakano T, Lu L, Hu X, Mizokami M, Orito E, et al. Characterization of hepatitis B virus genotypes among Yucpa Indians in Venezuela. J Gen Virol. 2001;82:359-65.

21. Cao GW. Clinical relevance and public health significance of hepatitis B virus genomic variations. World J Gastroenterol. 2009;46:5761-9.

22. Toan NL, le Song $H$, Kremsner PG, Duy DN, Binh VQ, et al. Impact of the hepatitis $B$ virus genotype and genotype mixtures on the course of liver disease in Vietnam. Hepatology. 2006:43:1375-84.

23. Yin J, Zhang H, Li C, Gao C, He Y, et al. Role of hepatitis B virus genotype mixture, subgenotypes C2 and B2 on hepatocellular carcinoma: compared with chronic hepatitis B and asymptomatic carrier state in the same area. Carcinogenesis. 2008;29:1685-91.

24. Erhardt A, Blondin D, Hauck K, Sagir A, Kohnle T, et al. Response to interferon alfa is hepatitis $B$ virus genotype dependent: genotype $A$ is more sensitive to interferon than genotype D. Gut. 2005:54:1009-13.

25. Wai CT, Chu CJ, Hussain M, Lok AS. HBV genotype B is associated with better response to interferon therapy in $\mathrm{HBeAg}(+)$ chronic hepatitis than genotype C. Hepatology. 2002;36:1425-30.

26. Chan $\mathrm{HL}$, Hui AY, Wong ML, Tse AM, Hung LC, et al. Genotype $C$ hepatitis $B$ virus infection is associated with an increased risk of hepatocellular carcinoma. Gut. 2004;53:1494-8.

27. Chan HL, Wong GL, Tse CH, Chim AM, Yiu KK, et al. Hepatitis B Virus Genotype C Is Associated With More Severe Liver Fibrosis Than Genotype B. Clin Gastroenterol Hepatol. 2009;7:1361-6.

28. Chu CJ, Hussain M, Lok AS. Hepatitis B virus genotype B is associated with earlier $\mathrm{HBeAg}$ seroconversion compared with hepatitis B virus genotype $\mathrm{C}$. Gastroenterology. 2002;122:1756-62.

29. Livingston SE, Simonetti JP, Bulkow LR, Homan CE, Snowball MM, et al. Clearance of hepatitis $B$ e antigen in patients with chronic hepatitis $B$ and genotypes A, B, C, D, and F. Gastroenterology. 2007;133:1452-7.

30. Alam MM, Zaidi SZ, Malik SA, Shaukat S, Naeem A, et al. Molecular epidemiology of Hepatitis B virus genotypes in Pakistan. BMC Infect Dis. 2007;7:115.

31. Noorali S, Hakim ST, McLean D, Kazmi SU, Bagasra O. Prevalence of Hepatitis B virus genotype D in females in Karachi, Pakistan. J Infect Dev Ctries. 2008; 2:373-8.

32. Baig S, Siddiqui A, Chakravarty R, Moatter T. Hepatitis B virus subgenotypes D1 and D3 are prevalent in Pakistan. BMC Res Notes. 2009;2:1.

33. Naaz A. Variability analysis in immunogenic region of surface gene of Pakistani isolates of Hepatitis B Virus. PhD thesis. University of Punjab 2001, pp. 68-113

34. Idrees M, Khan S, Riazuddin S. Common genotypes of hepatitis B virus. J Coll Physicians Surg Pak. 2004;14:344-7.
35. Ali M, Idrees M, Ali L, Hussain A, Rehman IU, et al. Hepatitis B virus in Pakistan: A systematic review of prevalence, risk factors, awareness status and genotypes. Virol J. 2011;8:102.

36. Naito H, Hayashi S, Abe K. Rapid and Specific Genotyping System for Hepatitis B Virus Corresponding to Six Major Genotypes by PCR Using Type-Specific Primers. J Clin Microbiol. 2001;39:362-4.

37. Abbas Z, Muzaffar R, Siddiqui A, Naqvi SAA, Rizvi SAH. Genetic variability in the precore and core promoter regions of hepatitis $B$ virus strains in Karachi. BMC Gastroenterol. 2006;6:20.

38. Hakim ST, Kazmi SU, Bagasra O. Seroprevalence of Hepatitis B and C Genotypes Among Young Apparently Healthy Females of Karachi-Pakistan Lib J Med. 2008;3:66-70.

39. Ahmed CS, Wang ZH, Bin Z, Chen JJ, Hou JL. Hepatitis B virus genotypes, subgenotypes, precore, and basal core promoter mutations in the two largest provinces of Pakistan. J Gastroenterol Hepatol. 2009:24:569-73.

40. Lindh M, Hannoun C, Dhillon AP, Norkrans G, Horal P. Core promoter mutations and genotypes in relation to viral replication and liver damage in East Asian hepatitis B virus carriers. J Infect Dis. 1999;179:775-82.

41. Kao JH, Chen PJ, Lai MY, Chen DS. Hepatitis B genotypes correlate with clinical outcomes in patients with chronic hepatitis B. Gastroenterology. 2000;118:554-9.

42. Orito E, Mizokami M, Sakugawa H, Michitaka K, Ishikawa K, et al. A casecontrol study for clinical and molecular biological differences between hepatitis B viruses of genotypes B and C. Hepatology. 2001;33:218-23.

43. Sumi H, Yokosuka O, Seki N, Arai M, Imazeki F, et al. Influence of hepatitis B virus genotypes on the progression of chronic type $\mathrm{B}$ liver disease. Hepatology. 2003;37:19-26.

44. Chu CM, Liaw YF. Genotype C hepatitis B virus infection is associated with a higher risk of reactivation of hepatitis $B$ and progression to cirrhosis than genotype B: a longitudinal study of hepatitis B e antigen-positive patients with normal amino-transferase levels at baseline. J Hepatol. 2005;3:411-7.

45. Gandhe SS, Chadha MS, Arankalle VA. Hepatitis B virus genotypes and serotypes in western India: lack of clinical significance. J Med Virol. 2003;69:324-30

46. Zeng G, Wang Z, Wen S, Jiang J, Wang L, et al. Geographic distribution, virologic and clinical characteristics of hepatitis B virus genotypes in China. J Vir Hepat. 2005:12:609-17.

47. Baig S, Siddiqui A, Ahmed W, Qureshi H, Arif A. The association of complex liver disorders with HBV genotypes prevalent in Pakistan. Virol J. 2007:4:128.

\section{Submit your next manuscript to BioMed Central and we will help you at every step:}

- We accept pre-submission inquiries

- Our selector tool helps you to find the most relevant journal

- We provide round the clock customer support

- Convenient online submission

- Thorough peer review

- Inclusion in PubMed and all major indexing services

- Maximum visibility for your research

Submit your manuscript at www.biomedcentral.com/submit 